\title{
TAXATION OF INCOME OF DECEDENTS
}

\section{George Craven $\dagger$}

The federal income tax statute dealing with income in respect of decedents ${ }^{1}$ has been in force for eleven years, and during that period the courts have solved many of the income tax problems arising under that statute as well as companion problems arising under the estate tax statute. As an aid to understanding the purpose and meaning of the income tax statute, it is helpful to review the considerations which gave rise to its enactment.

\section{Treatment Prior to 1942 of Income Accrued at Death}

Prior to the Revenue Act of 1934, if an individual filed his federal income tax returns on a cash basis, income which had accrued to him but was uncollected at the time of his death was not taxable to the decedent, because it had not been received by him. It was subject to estate tax as an asset of his estate, and it was held to be corpus and not income to the estate and therefore not subject to income tax to the estate. ${ }^{2}$ The result was that the income escaped income tax entirely.

The Revenue Act of 1934 provided for the first time for including in the final return of a cash basis decedent amounts of income accrued but uncollected at the time of death. ${ }^{3}$ Similarly, that Act allowed as deductions in such decedent's final income tax return items otherwise deductible which had accrued but were unpaid at the time of his death. ${ }^{4}$ Those provisions remained in force until the enactment of the Revenue Act of 1942.

The statute as amended in 1934 was found to operate inequitably against decedents. Although it was designed merely to prevent accrued income from escaping income tax and to allow certain deductions accrued at death, ${ }^{5}$ the statute as construed by the courts in cer-

$\dagger$ A.B., LL.B., Mercer University; Member of Georgia, Florida, New York and Pennsylvania Bars. 830 (1942).

1. Int. Rev. Code $\S 126$, as added by the Revenue Act of $1942, \S 134,56$ Stat.

2. Nichols v. United States, 64 Ct. Cl. 241 (1927), cert. denied, 277 U.S. 584 (1928); William G. Frank, 6 B.T.A. 1071 (1927); G.C.M. 8826, IX-2 Cum. BuLL. 194 (1930).

3. Revenue Act of 1934, § 42, 48 Stat. 694 (1934).

4. Revenue Act of 1934, $\S 43,48$ Star. 694 (1934).

5. H.R. Rep. No. 704, 73d Cong., 2d Sess. 24 (1934) ; Sen. Rep. No. 558, 73d Cong., $2 \mathrm{~d}$ Sess. 28 (1934). See Helvering v. Enright, 312 U.S. 636, 639 (1941). 
tain cases caused large amounts to be taxed in a decedent's final return. For example, in Helvering $v$. Enright, ${ }^{6}$ involving the final income tax return of a deceased member of a law firm, it was held that the return should include not only the decedent's share of legal fees accrued to the partnership in an accounting sense, but also his estimated share of fees which the firm had earned on uncompleted legal matters, where it was possible to determine the value of the services on a quantum meruit basis. It was so held even though the partnership was on a cash basis. The court said: "Accruals here are to be construed in furtherance of the intent of Congress to cover into income the assets of decedents, earned during their life and unreported as income, which on a cash return, would appear in the estate returns." 7 There was a similar decision in a companion case involving a deceased member of a medical partnership. ${ }^{8}$ The result in many cases was to pyramid or "bunch up" in a decedent's final return a large amount of income, some of which might never be collected by his estate.

On the other hand, where a decedent's estate settled litigation pending at the time of his death and made a payment which would have been deductible as a business expense if made by the decedent, it was held that the amount was not deductible in the decedent's final return because the amount of the liability was not known or admitted at the time of death. ${ }^{9}$

\section{Section 126}

When the Revenue Bill of 1942 was being considered by Congress, the Treasury Department recommended an amendment to the income tax law to eliminate the "bunching up" of income in a decedent's final return which resulted from the decision in the Enright case. $^{10}$ It was suggested that, in order to avoid this hardship, Congress abolish the method then in force of taxing such income and that it substitute a method which "taxes the income to the persons who actually receive it," that is, "to the estate or to the heir or legatee as the case may be." 11 Congress adopted the changes suggested by the Treasury Department in order to continue to subject such accrued

6. 312 U.S. 636 (1941).

7. Id. at 644-5.

8. Pfaff v. Comm'r, 312 U.S. 646 (1941).

9. Comm'r v. United States Trust Co., 143 F.2d 243 (2d Cir.), cert. denied, 323 U.S. 727 (1944).

10. See statement of Randolph E. Paul, Tax Adviser to the Secretary of the Treasury, Hearings before Committee on Ways and Means on H.R. 7378, 77th Cong., 2 d Sess. 89 (1942). See also 2 Mertens, Law of Federal Inconse TaxaTION $\$ 12.100$ (Supp. 1953).

11. Hearings, supra note 10. 
income to income tax but to grant relief from hardships resulting in many cases from including such income in the decedent's final return. ${ }^{12}$

The change suggested by the Treasury Department was accomplished by Section 134 of the Revenue Act of 1942, which struck out the provisions including accrued income and allowing accrued deductions in the final return of a cash basis decedent ${ }^{13}$ and which added to the Internal Revenue Code a new Section 126, setting forth the rules for taxing such income.

\section{General Statutory Plan}

Section 126 abandons the terms "accrued income" and "accrued deductions" and uses instead the terms "income in respect of a decedent" and "deductions in respect of a decedent." The pattern of the statute is to tax such items of gross income, in the year in which they are actually received, $(A)$ to the decedent's estate, if it acquires from the decedent the right to such income; $(B)$ if such right is not acquired by the estate, to the person who acquires such right by reason of the decedent's death; or $(C)$ if the estate acquires such right from the decedent and subsequently distributes it to an individual, to such individual who subsequently receives the income. ${ }^{14}$ For example, if the decedent leaves as part of his general or residuary estate a bond on which interest of $\$ 100$ was accrued at the time of death and the interest is received by his estate after his death, the accrued interest is taxable as income to the estate. If the bond is bequeathed specifically to a named legatee, the accrued income is taxable to the legatee in the year in which received. If the bond forms part of the estate passing to the executors, and before the interest is received the executors distribute the bond to a general or residuary legatee, the interest is taxable to the legatee when received by him. ${ }^{15}$

If a right to receive an item of "income in respect of a decedent" is transferred by sale, exchange or other disposition by the estate or

12. H.R. REP. No. 2333, 77th Cong., 2d Sess. 83 (1942); SEN. REP. No. 1631, 77th Cong., 2d Sess. 100 (1942).

13. INT. REv. CODE $\$ \S 42,43$.

14. INt. Rev. Code $\$ 126($ a) (1).

15. The provisions of $\S 126$ are applicable to years beginning after December 31 , 1942. (Revenue Act of 1942, \$134(f), 56 Stat. 832 (1942)). However, in cases where the decedent's final taxable period began after December 31,1933 , and before January 1, 1943, an option was afforded to the decedent's personal representative and the beneficiaries of his estate to elect to have items of income and deductions accrued at the time of death excluded from the decedent's final return and included in the returns of the estate or beneficiaries under the provisions of $\$ 126$. (Revenue Act of 1942, $\$ 134(\mathrm{~g}), 56$ Stat. 832 (1942)). Provision was made for the refund of taxes paid on the decedent's final return in cases where the election was exercised in the manner prescribed by statute. (Revenue Act of 1942, §134(g), 56 STAT. 832 (1942)) ; U.S. Treas. Reg. 111, \$29.126-4 (1943)). The latest date under the regulations for exercising such election was January 1, 1944. (U.S. Treas. Reg. 111, $\$ 29.126-4$ (b) (1943)). 
individual who acquires such right from the decedent, there is includible in the income of the estate or individual in the year in which the transfer is made the fair market value of such right at the time of the transfer plus the amount by which any consideration for the transfer exceeds such fair market value. ${ }^{18}$ If, then, the right is sold for an amount in excess of its fair market value, the entire amount so received will be includible in the gross income of the transferor. The regulations state that if the right to receive such income is disposed of "by gift or bequest" by the person acquiring the right from the decedent, the fair market value of the right at the time of such disposition must be included in the gross income of the donor or testator. ${ }^{17}$ However, a distribution of such right by the estate or trust to a specific legatee or a residuary legatee or by a testamentary trust to a remainderman is not considered a transfer which causes the value of the right to be includible in the income of the estate or trust. ${ }^{18}$

The Commissioner has ruled that where the widow of a deceased life insurance agent acquired from her husband the right to receive renewal commissions and she died before receiving the full amount of the commissions, the value of the uncollected portion was not includible in her final return. ${ }^{19}$ In view of the language of the statute and regulations, this ruling may be open to question. The result seems fair, however, and it should be made certain by a clarifying amendment to the statute.

An amount of income in respect of a decedent is treated in the hands of the estate or legatee ${ }^{20}$ as if it had been acquired in the same transaction in which the decedent acquired the right to such income, and it retains in the hands of the estate or legatee the same character, such as tax exempt income, long-term capital gain or ordinary income, which it would have had if received by the decedent during his lifetime. ${ }^{21}$

Certain deductions and credits "in respect of a decedent" are allowed, in the year of payment, to the decedent's estate, except that if the estate is not liable to discharge the obligation to which the deduction or credit relates, the deduction or credit is allowed to the individual who acquires an interest in property of the decedent subject to such obligation and who pays the obligation. ${ }^{22}$ The items so deductible

16. Int. Rev. Code $\$ 126$ (a) (2).

17. U.S. Treas. Reg. 118, §39.126(a)-1(f) (1953).

18. Ibid.

19. See 5 CCH 1952 FEd. TAx Rep. \6221 (Letter dated Dec. 27, 1951).

20. The term "legatee" is used throughout this article to refer to any person other than the decedent's estate who, by reason of the death of the decedent, acquires the right to receive an amount of income in respect of a decedent.

21. INT. REv. CoDE $\S 126$ (a) (3).

22. INT. Rev. CODE $\S 126(\mathrm{~b})$. 
are limited to those allowable by Section 23 (a), (b) and (c) for business and nonbusiness expenses, interest, and taxes, and the credit is that allowable by Section 31 for foreign taxes on income. For example, if an heir or devisee acquires directly from the decedent real property on which taxes had become a lien at the time of death, such heir or devisee on paying the taxes will be entitled to the same deduction for such taxes to which the decedent would have been entitled if he had made the payment during his lifetime. ${ }^{23}$ Similarly, if an individual acquires from the decedent a right to an item of income on which foreign income taxes must be paid, such individual on paying the foreign taxes will be entitled to the credit provided for in Section $31 .{ }^{24}$

The deduction for depletion under Section $23(\mathrm{~m})$ of the Code is allowed to the estate or legatee receiving the income to which the deduction relates. ${ }^{25}$ This provision is significant only in the case of percentage depletion. The deduction for depletion based on cost or discovery value under Section $114(\mathrm{~b})(1)$ or (2), just like the deduction for depreciation under Section 23(1), computed to the date of death is allowable on the decedent's final return, and those who acquire the property on the decedent's death will compute their deduction from that date. However, the deduction for percentage depletion under Section 114(b) (3) is allowable to the person who receives the income to which the deduction relates, and the regulations state that the person entitled to such deduction on account of income in respect of a decedent is the person who receives the income, whether or not he receives the property from which such income is derived. ${ }^{28}$

Deduction for Estate Tax:-Items of "income in respect of a decedent" to which the decedent had an enforceable right at the time of his death, being property of the decedent, are subject to estate tax in his estate as well as to income tax. ${ }^{27}$ In order to grant partial relief from this double taxation, the statute allows as an income tax deduction to the estate or other person entitled to such items of income a proportionate part of the estate tax attributable to the excess of the value of the items of accrued income over the items of accrued deductions which are included in the estate tax return. ${ }^{28}$ The statute pro-

23. U.S. Treas. Reg. 118, §39.126(b)-1 (a) (1953).

24. Ibid. (1953).

25. INT. REv. CoDE $\$ 126(b)(2)$; U.S. Treas. Reg. 118, $\$ 39.126(b)-1$ (b)

26. U.S. Treas. Reg. 118, $\S 39.126$ (b)-1(b) (1953).

27. INT. Rev. Code $\$ 811$ (a).

28. INT. Rev. Code $\S 126($ c). 
vides that the estate tax attributable to such net value, that is, the excess of income over deductions, "shall be an amount equal to the excess of the estate tax over the estate tax computed without including in the gross estate such net value." ${ }^{29}$

The estate tax so deductible is the difference between (1) the federal estate tax, reduced by the credit for state death taxes, as originally computed and (2) the federal estate tax, reduced by the credit for state death taxes, recomputed after eliminating the net accruals from the taxable estate. , This means that the allowable deduction is the federal estate tax at the highest bracket, less the credit for state death taxes, on the value of the net accruals subjected to estate tax. The amount of the estate tax which is allowable as an income tax deduction each year to the estate or legatee is an amount which bears the same ratio to the portion of the estate tax attributable to net accruals which the value for estate tax of the gross accruals received by the estate or legatee in that year bears to the total value for estate tax purposes of all the gross accruals which are subjected to estate tax. Thus, although the accrued deductions are taken into consideration in arriving at the net accruals on which estate tax is payable, the deductions are disregarded in determining the portion of the estate tax which is deductible each year.

The following example of the determination of the deduction for estate tax is taken from the regulations: ${ }^{30}$

An attorney, who was on a cash basis, was entitled to a fee for services rendered in a case not completed at the time of his death, which fee was valued in his estate at $\$ 1,000$, and to accrued interest on bonds which was valued at $\$ 500$, making a total of $\$ 1,500$ which was included in the gross estate on account of items of income in respect of a decedent. Deductions were taken on the estate tax return for $\$ 150$ of business expenses for which the estate was liable and for $\$ 50$ of taxes accrued on property owned by the decedent, making a total of $\$ 200$ for accrued deductions. The gross estate was $\$ 185,000$ and the net estate before taking the specific exemption was $\$ 170,000$, on which the total federal estate tax, less the credit for state death taxes, was $\$ 23,625$. In the year following the death of the decedent, his estate collected the legal fee in the amount of $\$ 1,200$ (valued for estate tax at $\$ 1,000$ ), which amount was included in the income of the estate. The estate was entitled to a deduction, in computing its net income for such year, of $\$ 260$ on account of the estate tax attributable to such income, which deduction is computed as follows:

29. INT. Rev. CoDe $\S 126$ (c) (2) (C).

30. U.S. Treas. Reg. $118, \S 39.126$ (c)-1 (b) (1953). 
(a) (1) Value of income in respect of decedent included in computing gross estate

(2) Deductions in computing gross estate for claims representing deductions in respect of decedent

(3) Net value of income in respect of decedent included in gross estate

(b) (1) Federal estate tax less credit for state death taxes

(2) Less estate tax computed without including $\$ 1,300$ (item (a) (3) above) in gross estate $\$ 23,235$

(3) Portion of estate tax attributable to $\$ 1,300$ $\$ 390$

(c) (1) Value in gross estate of income received by estate in taxable year $(\$ 1,200)$

(2) Value in gross estate of all items in respect of decedent

(3) Portion of estate tax deductible on receiving $\$ 1,200$ fee $\left(\frac{1,000}{1,500} \times \$ 390\right) \quad \$ 260$

The allowance of a deduction for the estate tax paid on items which will be subject to income tax to the estate or legatee provides only partial relief from double taxation. In order to provide complete relief it would be necessary to allow a credit, rather than a deduction, for the estate tax. The argument could be made that a deduction, rather than a credit, is proper because, where a decedent receives income during lifetime, he is required to pay income tax on such income and where estate tax is payable on the income, the income tax payable on the lifetime return is allowable as a deduction and not as a credit on the estate tax return. However, income received during lifetime is available for living expenses, and if consumed during lifetime, is not subject to estate tax. On the other hand, income "in respect of a decedent" is subjected to estate and income taxes before it is available to the widow or other beneficiary for living expenses.

The allowance of an income tax deduction for estate tax on income taxable under Section 126(a) presents problems to be considered in drafting a will which makes use of the estate tax marital deduction. ${ }^{31}$

31. INT. REv. CODE $\$ 812(\mathrm{e})$. 
If the right to receive income "in respect of a decedent" is bequeathed to the surviving spouse and is allowed in whole or in part as an estate tax marital deduction, a recomputation of the estate tax after eliminating such income would result in a reduced marital deduction and would reduce the amount of estate tax otherwise attributable to such income. The maximum deduction for estate tax on such income can be obtained by providing that the bequest to the surviving spouse shall be satisfied out of other property of the decedent's estate. But even if that is done, the recomputation of the estate tax after eliminating the Section 126(a) income might reduce the marital deduction by reducing the adjusted gross estate and thus reduce the amount of estate tax attributable to such income. ${ }^{32}$

Effect of Income Tax on Estate Tax Value:-Although the estate tax is allowed as a deduction on the income tax return of the estate or beneficiary, the statute makes no provision for allowing the income tax payable by the estate or beneficiary as an estate tax deduction or in reduction of the value at which the accrued income is includible in the gross estate. It needs no argument that a bond having a market value of $\$ 10,000$ is more valuable than accrued income of $\$ 10,000$ on which the estate or a legatee must pay income tax of say $40 \%$ after deducting the estate tax, and equitable considerations seem to require the allowance of the income tax in reduction of the estate tax value.

The estate tax statute states that no deduction shall be allowed for income tax upon income received after the death of the decedent. ${ }^{33}$ However, that provision was included in the statute for the first time by Section 403 of the Revenue Act of 1918, and the report of the House Ways and Means Committee on that section shows that the provision was intended to apply to income earned by the estate during the period of administration and which was not included in the estate tax return. $^{34}$ No attempt appears to have been made in the courts to establish the right to the deductions. This may be because of the rather definite language of the statute. However, in view of the clarity of the legislative history, a substantial chance of success could probably be anticipated. ${ }^{35}$

If the income tax should be allowed in reduction of the estate tax value, then, since the estate tax is deductible on the income tax

32. See 5 CCH 1952 FEd. TAX REP. \6162 (Letter dated March 7, 1952).

33. INT. REv. CODE $\S 812$ (b).

34. H.R. Rep. No. 767, 65th Cong., 2d Sess. 22 (1918), 1939-1 Cum. Buld. Part 2102.

35. See United States v. American Trucking Ass'n, Inc., 310 U.S. 534, 543 (1940), in which the Court said that where the plain meaning of words of the legislature "has led to absurd or futile results . . . [the Court] has looked beyond the words to the purpose of the act." 
return, the amount of each tax would depend on the amount of the other. The determination of the amount of each tax would require a mathematical formula similar to that used to compute the amount of the estate tax deduction for a residuary bequest to charity where the federal estate tax is payable out of the residue. ${ }^{\mathbf{3}}$ For example, if the accrued income is $\$ 10,000$, the applicable estate tax rate $30 \%$ and the applicable income tax rate $40 \%$, it will be found that the amount of estate tax payable on the accrued income after deducting the income tax is approximately $\$ 2,040$, and that the amount of income tax payable on such income after deducting the estate tax is approximately $\$ 3,180$, amounting to total taxes of $\$ 5,220$. If the estate tax alone is allowed as a deduction, the estate tax is $\$ 3,000$, the income $\operatorname{tax}$ is $\$ 2,800$ and total taxes are $\$ 5,800$.

Deductions Allowable for either Estate Tax or Income Tax:The deductions described in Section 23(a), (b) and (c) which are accrued and unpaid at death are allowable on the income tax return of the estate or legatee under Sections $126(\mathrm{~b})$ and 23(w) and also on the estate tax return of the decedent's estate as claims against the estate under Section 812(b). There is thus a duplication of the tax benefit derived from such deductions, although such benefit is lessened by reason of the fact that the existence of such deductions on the estate tax return reduces the estate tax on net accruals which is allowable as an income tax deduction to the estate or legatee.

There are certain expenditures of the estate accruing after death which may be deducted on either the estate tax return or the income tax return of the estate, but which may not be deducted on both. Examples of such items are executors' commissions and investment expenses, certain attorneys' fees, and state stock transfer taxes, which are income tax deductions under Section 23(a) and (c) and which are also deductible on the estate tax return as administration expenses under Section 812 (b). For years prior to the effective date of the amendment described below, it was held that even though certain deductions were allowable for estate tax purposes, they were also allowable as income tax deductions. ${ }^{37}$ However, the income tax statute has been amended by the addition of Section $162(\mathrm{e})$ of the Code, ${ }^{38}$ which provides that amounts deductible on the estate tax return under Section $812(\mathrm{~b})$ shall not be allowed as income tax deductions under Section 23 (except subsection (w) mentioned above), unless the estate files within the time and in the manner and form

36. See INT. REv. Code $\$ 812(d)$.

37. Robert J. Kleberg, 31 B.T.A. 95 (1934); Helvering v. Highland, 124 F.2d 556 (4th Cir. 1942). See H.R. Rep. No. 2333, 77th Cong., 2d Sess. 75 (1942).

38. Added by the Revenue Act of 1942, $\$ 161$ (a), 56 STAт. 861 (1942), fully effective for 1942 and subsequent years. 
prescribed by the Commissioner a waiver of the right to such deductions on the estate tax return. The regulations state that such waiver "should be filed with the return for the year for which the item is claimed as a deduction, or with the Commissioner, or with the district director of internal revenue for the internal revenue district in which such return was filed, for association with the return." 39

The executor or administrator is thus given the right to elect whether to claim such deductions on the estate tax return or on the income tax return of the estate. If he fails to exercise the election in the manner prescribed by the regulations, the deductions are allowable on the estate tax return and not on the income tax return. ${ }^{40}$ If a proper waiver is filed, the estate may deduct on its income tax return for a particular year items otherwise allowable on the estate tax return under Section 812 (b) without forfeiting its right to a deduction on the estate tax return for such administration expenses paid in another taxable year. ${ }^{41}$

\section{Right of Estate to Deduct Distributed Income}

It was held by the Tax Court in Estate of Ralph R. Huesman, ${ }^{42}$ and Rose $J$. Linde ${ }^{43}$ that if a decedent's estate receives items of income in respect of a decedent, it may not take a deduction under Section 162 (c) of the Code for amounts of such income distributed during the taxable year to beneficiaries. The reasoning of these cases is that such items constitute part of the corpus of the estate under the state law, and since they are not distributed as income under the state law, they may not be deducted as distributions of income. The Linde case held further that after the distribution to a legatee of the right to receive an item of income in respect of a decedent, the income when received was taxable to the legatee.

The distributee in the Huesman case was a charitable organization which was entitled to a percentage of the decedent's residuary estate and was not entitled to receive income. If that decision can be supported, it is on the ground that an estate cannot take a deduction under Section 162(c) for a distribution of income to a legatee entitled to receive only principal. The Tax Court's decision was affirmed on that ground by the Court of Appeals for the Ninth Circuit,4 and

39. U.S. Treas. Reg. 118, § 39.162-1(a) (1953).

40. See Estate of C. M. Sutton, 5 CCH TC MEM. DeC. 213 (1946).

41. I.T. 4048, 1951-1 Cum. Bull. 39, 40.

42. 16 T.C. 656 (1951), aff'd, 198 F.2d 133 (9th Cir. 1952).

43. 17 T.C. 584 (1951).

44. 198 F.2d 133 (1952). 
the appellate court refused to say whether income includible in the gross income of an estate under Section 126 can in no instance be deducted as a distribution of income under Section 162.

The Tax Court's decisions in the Huesman and Linde cases are of doubtful soundness in holding that an estate should be denied a deduction for a distribution of taxable income merely because such income is classified as principal under the state law. There is nothing in Section 126 or Section 162(c) which denies a deduction to the estate merely because the distributed income is regarded as principal under the state law. State law controls in determining whether an amount is properly distributed by a fiduciary to a beneficiary, ${ }^{45}$ but the federal income tax statutes have their own criteria for determining whether an amount is income, and state law should control on that question only where the federal taxing statute, by express language or necessary implication, makes its own operation dependent upon state law. ${ }^{46}$ Moreover, the statute governing income in respect of a decedent provides expressly that such income shall have the same character in the hands of the estate or legatee which it would have had in the hands of the decedent. ${ }^{47}$ Such amounts would be income and not principal if received by the decedent. There is nothing in the statute or Congressional committee reports to indicate that Congress intended to deny the right of the estate to a deduction for a distribution of income made taxable under Section 126(a). If there is doubt about the right to such a deduction, the doubt should be removed by a clarifying amendment to the statute.

Where a testator wishes to make bequests to charitable organizations and there is a possibility that at the time of his death there will be a substantial amount of income taxable under Section 126(a), it seems advisable, in view of the Tax Court's decisions in the Huesman and Linde cases, to make a specific bequest to the charities of the right to receive such income. If that is done, the income will not be includible in the return of the estate, and will be exempt from income tax ${ }^{48}$ as well as estate tax. ${ }^{49}$

Even if the Huesman and Linde cases are correct on their facts, they have no application to a case where an item of income in respect of a decedent under the terms of the will is permanently set aside for a charitable organization as part of the principal of the estate. Such

45. Freuler v. Heivering, 291 U.S. 35 (1934).

46. Lyeth v. Hoey, 305 U.S. 188 (1938); Burnet v. Harmel, 287 U.S. 103

(1932); Weiss v. Wiener, 279 U.S. 333 (1929).

47. INT. REv. CODE \&126(a) (3).

48. INT. REv. CoDE $\$ \$ 126(a), 101(6)$.

49. Int. REv. Code $\$ 812$ (d). 
income, even though principal under the state law, would not be different from capital gains realized by the estate which are considered income permanently set aside for a charitable organization and consequently deductible under Section $162(a) .{ }^{50}$ The right to the deduction in such cases is not dependent upon a distribution, and the mere receipt of the income by the executor entitles the estate to the deduction.

\section{Compensation for Personal Services}

\section{Income Tax}

There is no definition in the statute of the term "income in respect of decedents," and the Congressional committee reports on the Revenue Bill of 1942 indicate that the term was intended to apply to income accrued to the decedent at the time of his death which prior to the 1942 Act was includible in his final return. ${ }^{51}$ However, the courts have extended the application of Section 126 far beyond items which could be said in any sense to have accrued to the decedent at the time of his death or even to which the decedent had an enforceable right. One of the most far-reaching decisions is O'Daniel's Estate v. Commissioner, ${ }^{52}$ where the court held taxable to a decedent's estate a bonus based on the decedent's services to a corporation, the amount of which bonus was not determined until after the decedent's death. Although the decedent had no enforceable right to the bonus at the time of his death, the court said that the amount "was plainly gross income in respect of the decedent," that the right to receive it was acquired by the decedent's estate from the decedent, and that consequently the amount was taxable as income to the estate under Section $126(a) .{ }^{53}$

It was held in Varnedoe $v$. Allen ${ }^{54}$ that payments made to the widow of a state employee constituted income to the widow as compensation for personal services of the husband, where the payments were made pursuant to a state statute and deductions were made regularly under the statute from the husband's salary. The court said it was not necessary that the services be rendered by the payee and that the payments were awarded to the widow in consideration of the

50. Bowers v. Slocum, 20 F.2d 350 (2d Cir. 1927) ; G.C.M. 423, V-2 Cun. Bull. 53 (1926) ; G.C.M. 10423, XI-2 CuM. BuLL. 127 (1932); Peoples Trust Co., 10 B.T.A. 1385 (1928); Potter v. Bowers, 89 F.2d 687 (2d Cir. 1937).

51. H.R. Rep. No. 2333, 77th Cong., 2d Sess. 83 (1942) ; SEN. Rep. No. 1631, 77th Cong., 2d Sess. 100 (1942).

52. 173 F.2d 966 (2d Cir. 1949).

53. Id. at $967-8$.

54. 158 F.2d 467 (5th Cir. 1946), cert. denied, 330 U.S. 821 (1947). 
services rendered by her husband. Although the Varnedoe case involved years when Section 126 was in force, the court did not cite that Section but held the payments taxable under Section 22(a), which defines gross income. The Bureau has ruled that similar payments are taxable to a deceased employee's estate under Section $126(\mathrm{a}),{ }^{\mathbf{5 5}}$ which means that a deduction is allowable to the estate or the widow for estate tax paid on the value of the right to receive the payments.

It seems clear that amounts paid by an employer to the estate or the widow of a deceased employee pursuant to contract as compensation for the decedent's services are taxable as income to the recipient under Section $126(a) .{ }^{56}$ Such payments to the widow of a deceased employee were held taxable to her even under the law in force prior to the enactment of Section 126.57 The rule is not so clear where the payments are voluntary and not pursuant to a contractual obligation of the employer.

Bureau rulings which were in force for many years stated that where the salary of a deceased employee was paid voluntarily to his widow for a limited period after his death, although the employer was entitled to deduct the payments as business expenses, they were a gratuity to the widow and were not includible in her income. ${ }^{58}$ The Tax Court in Louise $K$. Aprill ${ }^{59}$ followed the Bureau rulings and held that voluntary payments to a widow of a deceased employee "in recognition of the services rendered" by her husband to the employer were not taxable as income to her. Although the case involved a year when Section 126 was in force, the court did not refer to that section.

These earlier Bureau rulings were revoked or modified by I. T. $4027,{ }^{60}$ which states that regardless of whether such payments to the widow are voluntary or pursuant to an enforceable obligation, they are made in consideration of services rendered by the employee and are taxable as income to the widow. Despite that ruling, the Tax Court in Alice M. Macfarlane ${ }^{\text {B1 }}$ followed its decision in the Aprill case and, without referring to I.T. 4027 , held that such a voluntary payment to the employee's widow was not taxable as income to her.

55. I.T. 3744, 1945 Cum. Bull. 192.

56. See Estate of Arthur D. Davis, 11 CCH TC MEM. DEc. 814 (1952).

57. Flarsheim v. United States, 156 F.2d 105 (8th Cir. 1946) (involving income for the years 1933 and 1934).

58. I.T. 3329, 1939-2 Cum. Bull. 153; O.D. 1017, 5 Cum. Bul. 101 (1921).

59. 13 T.C. 707 (1949).

60. 1952-2 Cuns. Bull. 9.

61. 19 T.C. 9 (1952). 
The Bureau's present position was upheld in Bausch's Estate $v$. Commissioner, ${ }^{62}$ in which a corporation without obligation but in accordance with past practice made payments to the estates of deceased employees for a period of twelve months after their deaths of amounts equivalent to the employees' salaries. It was held that the payments were taxable as income to the respective estates under Section 126(a). There was a decision to the same effect in a case involving a year prior to the enactment of Section $126^{63}$

Where the widow of a deceased employee received an amount under a plan of the employer which provided for payments to dependents of deceased employees, and the plan stated that it was a voluntary plan and could be withdrawn at any time, but that the employer "guaranteed" payment according to the terms of the plan in force at the time of the employee's death, and where the amount was deducted by the employer as a business expense, it was held that there was an enforceable obligation to make the payment and that the amount was not a gift but was taxable as income to the widow for a year prior to the enactment of Section $126 .{ }^{64}$

The Bureau has ruled that amounts received by the widow or heirs of an employee pursuant to the terms of a voluntary death benefits plan of any employer, to which no contributions are made by the employee, represent compensation for services of the employee and are taxable to the recipient under Section 126(a), even though the employer reserves the right to designate the persons to whom the payments are to be made. ${ }^{65}$ The Tax Court held that a percentage of his employer's profits for the preceding year to which a decedent was entitled under his employment contract, but which had not been determined during the portion of the taxable year when he was alive, was taxable to his estate in the year of receipt and could not be considered income which was constructively received by the decedent during his lifetime. ${ }^{68}$

Survivor Annuity:-Where an annual amount is paid to the beneficiaries of a deceased employee under an employees' annuity plan which qualifies under Section 165 of the Code, the amount is taxable to the recipients in the manner and to the extent that it would have been taxable to the employee if he had lived, and where taxed as an

62. 186 F.2d 313 (2d Cir. 1951).

63. Brayton v. Welch, 39 F. Supp. 537 (D. Mass. 1941).

64. Sutro v. United States, 42-2 CCH U.S. TAX Cases 19523 (N.D. Cal. 1942). The court said that in a separate suit for a refund of estate tax paid on the amount, the case was dismissed and the refund made by the Government.

65. I.T. $3840,1947-1$ Cum. Bul.. 7.

66. Estate of Fred Basch, 9 T.C. 627 (1947). 
annuity, the amount contributed by the employee is deemed the consideration. ${ }^{67}$ The income tax law was amended in 1951 to provide that if a survivor's interest in a joint and survivor annuity contract is includible in the decedent's gross estate under Section 811 (without regard to whether any estate tax is payable), such interest shall be considered property acquired from the decedent and the value of the interest on the date of death (or optional valuation date) shall be deemed the consideration paid for the survivor's annuity ${ }^{68}$ This means that of the payments received by the survivor, only three per cent of the date of death value or other estate tax value will be taxable as income, and the excess each year will be excluded from income until the total of the excess equals the estate tax value. The amendment is applicable only where the decedent died after December 31, 1950.

The Commissioner has ruled that annuities paid from retirement funds to widows or other beneficiaries of deceased employees are taxable under Section 22(b) (2), and not under Section 126(a), and that no deduction is allowable for estate tax paid on the right to receive such amounts. ${ }^{69}$ The ruling is open to question. Its reasoning is that Section 126 was intended to apply to items of income which prior to the 1942 Act would have been includible in the final income tax return of a decedent; that an annuity payable to beneficiaries of a deceased employee would not have been includible under the earlier statute in the decedent's final return, and that the payments are governed exclusively by Section 22 (b) (2). As we have seen, Section 126(a) has been applied to amounts which could not conceivably have been held includible under the former statute in the decedent's final return, ${ }^{70}$ and Section 126 (a) undoubtedly applies to some items of income which are taxable also under subsections of Section $22 .^{71}$ The question can not be considered settled until passed upon by the higher courts. However, it is not so important now, in view of the 1951 amendment, referred to above, which gives the survivor annuitant a new basis.

Where the total amount to which a beneficiary is entitled under a qualified pension plan is paid within one taxable year to the beneficiary,

67. INT. Rev. CoDE $\$ \$ 22(b)(2), 165$ (b) ; U.S. Treas. Reg. 118, \$\$39.22(b) (2)5(c), 39.165-6(a) (1953).

68. Revenue Act of 1951, §303, 65 STAT. 483 (1951), amending INT. REv. Code $\S \S 22(\mathrm{~b})(2)$ and $113(\mathrm{a})(5)$, effective for years ending after December 31, 1950 , See Sen. Rep. No. 781, 82d Cong., 1st Sess. 52 (1951).

69. See 4 CCH 1947 Fed. TAx Rep. I 6132 (Letter dated Oct. 9, 1946) (summarized in 3 CCH 1953 FED. TAX REP. $(964.40$ ).

70. O'Daniel's Estate v. Comm'r, 173 F.2d 966 (2d Cir. 1949), see text at notes 52 and 53 , supra.

71. Compare Varnedoe v. Allen, 158 F.2d 467 (5th Cir. 1946), cert. denied, 330 U.S. 821 (1947), with I.T. 3744, 1945 CUM. BuLI. 192. 
the amount received in excess of the employee's contributions is taxable at capital gain rates. ${ }^{72}$ The Bureau has ruled that the capital gain provisions are applicable to an amount paid to a beneficiary of a deceased employee even though the employee received payments under the plan prior to his retirement. ${ }^{73}$ If the payments qualify as a survivor's interest in a joint and survivor annuity, the gain would be measured by the estate tax value of the interest.

Death Benefit Not in Excess of $\$ 5,000$ :- Some measure of relief from income tax was provided by Section 302 of the Revenue Act of 1951, amending Section 22(b) (1) (B) of the Code. The amendment, effective for 1951 and subsequent years, exempts from income tax amounts received under a contract of an employer providing for the payment of such amounts to the beneficiaries of an employee, paid by reason of the death of the employee, whether in a single sum or otherwise, with the limitation that the aggregate of the amounts excludible from gross income of all the beneficiaries of the employee under all such contracts of any one employer may not exceed $\$ 5,000$.

It makes no difference if the payments exceed $\$ 5,000$, but only $\$ 5,000$ of the aggregate payments by any one employer may be excluded from the gross income of all the beneficiaries. If the decedent was employed by more than one employer and he had a contract with each employer providing for such payments, the first $\$ 5,000$ of such payments received by the beneficiaries from each employer would be excludible from their gross income. The regulations ${ }^{74}$ provide that where the aggregate payments by an employer under such contract to the beneficiaries of the deceased employee exceed $\$ 5,000$, the $\$ 5,000$ exclusion shall be apportioned among the beneficiaries in the proportion that the amount payable to each bears to the total death payment under the contract.

The statute does not require that the contract of the employer be in writing. The regulations, ${ }^{75}$ however, say that there must be an "express" contract and that such contract shall be deemed to exist only if "(1) the employer and employee had entered into a written contract, not revoked before the employee's death, which required such payments or (2) the employer had an established plan (or program having the effect of a plan) making provision for such payments in the case of his employees generally, or for a class or classes of his employees;" and that in the latter case the contract will be deemed

72. INT. Rev. Code $\$ 165$ (b).

73. I.T. 3847, 1947-1 Cum. Bulz. 65.

74. U.S. Treas. Reg. 118, $\$ 39.22$ (b) (1) -2 (a) (1953).

75. U.S. Treas. Reg. 118, $\S 39.22$ (b) (1)-2(c) (1953). 
to exist between the employer and the employees to whom the plan applies, provided the plan had been communicated to such employees and had not been rescinded prior to the death of the particular deceased employee. They provide further that a payment made on account of the death of an employee from a pension trust exempt under Section 165 (a) shall be considered made by the employer for the purpose of the exclusion. However, the regulations limit the exclusion to amounts which, by the terms of the contract or the provisions of the plan, are specifically designated as a death payment, paid only by reason of the death of the employee; and they state that the exclusion does not apply to amounts with respect to which the deceased employee possessed, immediately prior to his death, a nonforfeitable right to receive the amounts while living.

\section{Estate Tax}

Where a decedent had resigned his position as managing trustee under a will and as an officer of corporations whose stocks were held in the trust, in consideration of a written contract providing for the payment to him of an annual sum for ten years and providing that on his death within that period the payments would be continued to his wife for the remainder of the period or until her prior death, and where the decedent died within the ten year period survived by his wife, the Tax Court held that the value at the date of his death of the right to the remaining payments was includible in his gross estate under Section $811(\mathrm{c}) .^{78}$ The court relied on cases upholding the estate tax' on the value of a survivor annuity under a contract purchased by the decedent. ${ }^{77}$ The Tax Court in other cases has held an amount includible in the estate of a deceased employee under Section 811 (a) or (c) where it has found that the employee's widow had a contractual right to receive the amount from the employer in consideration of services rendered by the employee. $^{78}$

The Bureau at one time ruled in G.C.M. $17817^{79}$ that a death benefit paid by an employer to the beneficiary designated by a deceased employee was not includible in the employee's gross estate where the employer reserved the right to withdraw or modify the plan at any time in reference to benefits, but guaranteed that death benefits would be paid "in accordance with the plan as it may be in effect

76. Estate of William L. Nevin, 11 T.C. 59 (1948).

77. Comm'r v. Clise, 122 F.2d 998 (9th Cir. 1941), cert. denied, 315 U.S. 821 (1942); Mearkle's Estate v. Comm'r, 129 F.2d 386 (3d Cir. 1942).

78. Estate of Paul G. Leoni, 7 CCH TC MEM. DeC. 759 (1948) ; Estate of Arthur W. Davis, 11 CCH TC MEM. DEC. 814 (1952).

79. 1937-1 Cư. BuLl. 281. 
at the date of death of an employee." That ruling was followed in Dimock v. Corwin. ${ }^{80}$ Although the case went to higher courts on other issues, the Government did not appeal on that point.

However, the Bureau in G.C.M. $27242^{81}$ ruled that where an employee has the right to designate the beneficiary of a death benefit plan to which all contributions are made by the employer, the amount payable on the employee's death is subject to estate tax in his estate as property owned by the decedent or as property which he transferred reserving certain powers or interests or as property passing under the exercise of a general power of appointment. Under the facts on which the ruling was based, the employer reserved the right to terminate or amend the plan, and on termination the trustee was required to pay over to the participating employees or their beneficiaries their participating interests. The employer had the right to amend the plan so as to eliminate the provision for payment of a death benefit on account of employees dying prior to the receipt of any benefits under the plan, provided the amendment did not destroy the right of an employee to receive a death benefit which had already become payable. The ruling modified G.C.M. 17817 and stated that Dimock v. Corwin should no longer be followed by the Bureau.

Where it has found that death payments by an employer to the beneficiary of a deceased employee were wholly voluntary, the Tax Court has held that the payments are not includible in the decedent's gross estate. ${ }^{82}$ It reached a similar conclusion in a case where a survivor annuity was payable to the wife of a deceased employee under an enforceable pension plan but the decedent had no right to designate a surviving annuitant and the annuity to the decedent and his wife was subject to reduction in amount or cancellation by the employer in the event of various contingencies, such as unauthorized acceptance of employment with a competitor, bankruptcy, or conviction of a felony. ${ }^{83}$ Where a deceased employee was required to contribute to a pension fund to which the employer also contributed and it was found that the pension plan created enforceable rights in third party beneficiaries, but that the decedent at the time of his death had a vested interest only in the return of his contributions, it was held that the estate tax did not apply to any part of the value of an annuity paid to his widow other than his contributions. ${ }^{84}$

80. 19 F. Supp. 56 (E.D.N.Y. 1937), aff'd on other grounds, 99 F.2d 799 (2d Cir. 1938), aff'd sub nom. United States v. Jacobs, 306 U.S. 363 (1939).

81. 1952-1 CuM. BuLL. 160.

82. Estate of Albert L. Salt, 17 T.C. 92 (1951) ; Estate of John C. Morrow, 19 T.C. 1068 (1953).

83. Estate of William S. Miller, 14 T.C. 657 (1950).

84. Estate of Emil L. Stake, 11 T.C. 817 (1948). 
Where an amount placed in trust by an employer as additional compensation was to be paid to persons designated in an employee's will, with provision for payment to his issue in default of appointment, and the deceased employee did not make an appointment, the Tax Court held that the amount paid on the employee's death was not includible in his gross estate under Section 811 (c), (d) or (f), because the decedent did not make a transfer of the amount, did not cut down any beneficial rights which he himself had and transfer such right to his issue, and did not make an appointment of the amount. ${ }^{85}$ The court pointed out that the amount would have been taxable under later statutes providing for estate tax on property over which a decedent has an unexercised power of appointment. ${ }^{86}$

Higgs' Estate v. Commissioner ${ }^{87}$ held not includible in the estate of a deceased employee under Section 811 (c) the value of his wife's survivor annuity under an employer's pension plan. The decedent exercised an election to receive a reduced annuity after his retirement so that an annuity would be paid to his wife for life after his death. The entire cost of the benefits was borne by the employer and the decedent's election became irrevocable during his lifetime. The Commissioner contended that the wife's survivor annuity was includible in the decedent's gross estate as a transfer by the decedent to take effect in possssion or enjoyment at or after his death and as a transfer reserving to himself the enjoyment for life. The Commissioner relied on cases holding taxable as part of a decedent's estate the value of the survivor's rights in a joint and survivor annuity contract purchased by the decedent. ${ }^{88}$ The Court of Appeals for the Third Circuit in the Higgs case said that under the 1949 amendment of Section 811 (c) relating to transfers made prior to October 8, $1949,,^{80}$ a transfer made prior to that date was not taxable as one to take effect at or after death unless the decedent had a reversionary interest, and since there was no reversionary interest in the decedent, the transfer was not taxable on that ground. The court found it unnecessary to decide whether there had been a transfer by the decedent. The court said further that the annuity contract providing the survivor benefits was purchased by the employer and not by the decedent;

85. Estate of Eugene F. Saxton, 12 T.C. 569 (1949).

86. Int. Rev. Code $\$ 811$ (f), as amended, Rev. Act of 1942, §403, 56 STAt. 942 (1942). Section 811(f) was amended further by Pub. L. No. 58, 82d Cong., 1st Sess. (June 28, 1951), effective as of October 21, 1942, which taxes property subject to an unexercised general power of appointment created after that date.

87. 184 F.2d 427 (3d Cir. 1950).

88. Comm'r v. Wilder's Estate, 118 F.2d 281 (5th Cir.), cert. denied, 314 U.S. 634 (1941) ; Comm'r v. Clise, 122 F.2d 998 (9th Cir. 1941), cert. denied, 315 U.S. 821 (1942); Mearkle's Estate v. Comm'r, 129 F.2d 386 (3d Cir. 1942).

89. Pub. L. No. 378, 81st Cong., 1st Sess. \$7 (Oct. 25, 1949). 
that the decedent had only the right to reduce his annuity in order to provide an annuity for his wife, and that the decedent did not reserve to himself under the instrument exercising the option an interest in the "property" transferred to his wife.

The Court of Appeals for the Second Circuit reached the same conclusion in Commissioner v. Treogood's Estate ${ }^{30}$ on similar facts and reasoning. There have been other decisions to the same effect by lower courts. ${ }^{91}$

The above decisions leave open the question whether such survivor annuity would be subject to estate tax where the employee's election is made after October 7, 1949. The Bureau ruled recently that an employee's election prior to October 8, 1949 to take a reduced annuity and provide a survivor annuity for his wife does not constitute a taxable transfer under Section 811 (c)(1)(B), but that where the election was made on or after that date, the value of the survivor's annuity is includible in the gross estate of the deceased employee under Section $811(\mathrm{c})(3)$ or Section $811(f){ }^{92}$

Group Life Insurance:-The estate tax statute includes in the gross estate of the insured proceeds of insurance policies on his life, receivable by beneficiaries other than his estate, if the insured either (a) paid premiums directly or indirectly or (b) has incidents of ownership in the policies. ${ }^{93}$ It was held in Estate of Judson C. Welliver ${ }^{94}$ and in Estate of Eugene F. Saxton ${ }^{95}$ that where a decedent's employer, for the purpose of providing additional compensation to his employees, took out a group life insurance policy on the lives of certain employees and the decedent received a policy for a certain amount and part or all of the premiums were paid by the employer, the proceeds were includible in the decedent's gross estate on the grounds that (1) the decedent had retained the right to change the beneficiary, which was an incident of ownership, and (2) the premiums paid by the employer were paid indirectly by the decedent.

Optional Valuation of Survivor Annuity:-Estate of John A. Hance ${ }^{96}$ presented an interesting question of valuation of a survivor annuity under the estate tax law. The decedent had purchased single

90. 194 F.2d 627 (2d Cir. 1952).

91. Hanner v. Glenn, 111 F. Supp. 52 (W.D. Ky. 1953); Herrick v. United States, 108 F. Supp. 20 (E.D.N.Y. 1952) ; Estate of M. Hadden Howell, 15 T.C. 224 (1950).

92. Rev. Rul. 158, 1953 Int. Rev. Bull. No. 17 at 18 (1953).

93. INT. REv. CoDE $\S 811(\mathrm{~g})$.

94. 8 T.C. 165 (1947).

95. 12 T.C. 569 (1949).

96. 18 T.C. 499 (1952). 
premium contracts providing for payment of an annuity to himself for life and thereafter to his widow for her life. The executor elected under Section 811 ( $j$ ) to have the assets valued one year after death. The widow died during the one-year period and the question was whether the loss of value due to her death should be reflected in the value of the survivor annuity. Section $811(j)$ forbids any adjustment in value "due to mere lapse of time," but it was held that the loss of value due to the widow's death was not an adjustment due to mere lapse of time, that such loss should be reflected in the value of the survivor annuity and that such value was limited to the payments actually received by the widow before her death.

\section{PARTNERSHIP INCOME}

\section{Income Received to Date of Death}

The death of a member of a partnership gives rise to a number of interesting income and estate tax problems. One of the first problems is the income tax treatment of income received by the partnership from the beginning of its taxable year to the date of death of a partner.

The income tax law provides that a member of a partnership must include in his income tax return his share of the partnership net income for its taxable year which ends within or with his taxable year. ${ }^{97}$ For example, if a partner files his returns on a calendar year basis and the partnership files its returns on the basis of a fiscal year ending June 30, the partner's return for the calendar year 1952 would include his share of partnership income for its fiscal year ending June 30, 1952.

Where there was no provision in the partnership agreement for continuation of the firm on the death of a partner (although the surviving partners did in fact continue the partnership business), it was held in Guaranty Trust Co. v. Commissioner ${ }^{98}$ that the deceased partner's final return should include his share of partnership income for its fiscal year which ended within his final taxable period and also his share of income from the beginning of the partnership's succeeding fiscal year to the date of death. The court construed "taxable year" as used in the statute to be synonymous with "accounting period," so that if the death of a partner terminates the partnership and consequently ends an accounting period, the decedent's final return must include his share of income for such period. If the partnership is on an accrual basis, the share of income includible

97. INT. Rev. CODE $\$ 188$.

98. 303 U.S. 493 (1938). 
in the final return of a cash basis decedent includes his share of income accrued to the partnership but uncollected at the time of death; but it does not include income accrued solely by reason of death, such as an interest in contingent fees of a law firm in uncompleted matters. ${ }^{99}$.

The Courts of Appeals for the Third, Fifth, and Eighth Circuits in Girard Trust Company v. United States, ${ }^{100}$ Henderson's Estate v. Commissioner ${ }^{101}$ and Commissioner v. Mnookin's Estate ${ }^{102}$ held that where there was a provision in the partnership agreement for continuation without interruption on the death of a partner, a deceased partner's final return was not required to include his share of partner-. ship income to the date of death. In the Girard Trust Company case the partnership was on a fiscal year ending June 30, and under the. partnership agreement on the death of a partner the partnership was to continue without interruption until the following June 30 and there was to be no accounting for profits until that time. The decedent died November 15,1942, and it was held that his share of partnership profits for the period July 1 to November 15, 1942 was not includible in his final return. The court implied that such share of income reduced by a share of the partnership loss for the remainder of its fiscal year was includible in the return of the decedent's estate for the calendar year 1943. Answering the Government's contention that partners earn income as it comes into the partnership business, the court said: "Congress has not seen fit to tax partnership. income as earned but rather as if each partner's earning occurred periodically at the end of each taxable year of the partnership." 103

The Court of Appeals for the Second Circuit in Commissioner v. Waldman's Estate ${ }^{104}$ expressed disagreement with the decisions in the Girard Trust Co. and Mnookin cases. The partnership agreement in the Waldman case provided that on the death of a partner his executor should have the right to continue as a partner in the business or to sell the decedent's partnership interest, and the executor elected to continue in the partnership. The partnership was on a fiscal year ending June 30 and the decedent, who died November 22, 1945, was on a calendar year. The court, relying on Guaranty Trust Co. v. Commissioner, ${ }^{105}$ held that the decedent's final return should include his share of partnership income for the period July 1 to November 22,

99. INT. Rev. Code $\S 42$ (a); U.S. Treas. Reg. 118, §39.42-1 (b) (1953).

100. 182 F.2d 921 (3d Cir. 1950).

101. 155 F.2d 310 (5th Cir. 1946).

102. 184 F.2d 89 (8th Cir. 1950).

103. $182 \mathrm{~F} .2 \mathrm{~d}$ at 925 .

104. 196 F.2d 83 (2d Cir. 1952).

105. 303 U.S. 493 (1938). 
1945. The court could have distinguished the Girard Trust Company and Mnookin cases on the ground that the partnership agreement in each of those cases bound the estate to leave the decedent's interest at the risk of the partnership business until the end of the fiscal year, while in the Waldman case the executor had the option to discontinue the decedent's interest and demand an accounting for his share of partnership income to the date of death. However, the court, one judge dissenting, did not choose to do so, but after citing those cases, said: ". . . we make no attempt to distinguish them but, with deference, reach the contrary decision which we think Guaranty Trust Co. v. Commissioner, supra, requires." 108

It has been held that the death of a partner during the taxable year does not terminate an accounting period for the surviving partners and does not require the inclusion in their returns of partnership income from the beginning of its fiscal year to the date of death. ${ }^{107}$ The Bureau ruled recently that a change in the membership of a partnership resulting from the death or withdrawal of a partner does not in itself effect a termination of the partnership and that the returns of a continuing partnership should continue to be filed on the basis of the annual accounting period previously established by the partnership. ${ }^{108}$ Except as applied to partnerships which continue under the provisions of the partnership agreement, it may be questioned whether the Bureau ruling is in harmony with the Guaranty Trust Co. decision.

The value of the decedent's interest in the partnership, including any accrued and uncollected income, is of course property of the decedent which is includible in his gross estate.

If the partnership and the decedent are on a cash basis, then, even in cases governed by the Guaranty Trust Co. case, the decedent's share of income accrued to the partnership but uncollected at death is not includible in the decedent's final return. Such income is taxable to the estate or beneficiary in the year of receipt, with a deduction allowable for estate tax paid on the right to receive such income. ${ }^{109}$

\section{Income Earned After Death}

Where income earned by a partnership after the death of a partner is paid to the deceased partner's estate or widow, the income and estate tax treatment of the income depends on whether it is used to purchase the deceased partner's interest for the surviving partners

106. 196 F.2d at 85.

107. Mary D. Walsh, 7 T.C. 205 (1946).

108. Rev. Rul. 144, 1953 Int. Rev. BuLl. No. 8 at 29 (1953).

109. INT. Rev. Code $\$ 126$ (a) and (c). 
or whether it is made pursuant to a contractual right of the estate or widow to participate in the partnership earnings after decedent's death as a partner, joint adventurer or otherwise, decedent's capital interest having been purchased with other funds. In Bull $v$. United States, ${ }^{110}$ the decedent was a member of a partnership in which no capital was invested and which derived its income from personal services. In accordance with the partnership agreement, the decedent's estate was entitled to share in partnership profits and losses for a period of one year after his death. The Commissioner contended that the estate's share of partnership income for the one-year period was subject to estate tax and also to income tax. It was held that such income was subject to income tax but was not subject to estate $\operatorname{tax}$.

Treasury representatives have contended and writers on tax subjects have suggested that in cases similar to the Bull case, the Commissioner may subject to estate tax the right to receive income for a period after the decedent's death, as distinguished from the income itself. However, that very contention was made by the Government in the Bull case and the court said that under the facts of that case, it was not permissible to place any value for estate tax purposes "on the mere right of continuance of the partnership relation inuring to Bull's estate." 111 The Court said further that the right to receive such income was not capital to the decedent when living and could not be such to his estate.

The Tax Court has applied the principle of the Bull case in several cases where a share of partnership income for a period after death was paid to a deceased partner's estate or widow pursuant to a contractual right to share in such earnings and not as payment for a capital interest of the decedent in the partnership.

Charles $F$. Coates ${ }^{112}$ involved a partnership agreement of an accounting firm which provided that on the death of a partner his estate should receive payment of his capital interest in the firm and that in addition, the estate should participate in partnership earnings, but not losses, for a period of five years after the decedent's death. It was held that the estate's share of income for a period after death was not paid to purchase or liquidate the decedent's partnership interest and was not taxable to the surviving partners. ${ }^{113}$

110. 295 U.S. 247 (1935).

111. Id. at 256 .

112. 7 T.C. 125 (1946).

113. The author is informed that after the decision was rendered in the Coates case the revenue authorities conceded that the right of the estate of the deceased partner to participate in partnership earnings after the date of death was not subject to estate tax. 
In cases involving analogous facts, it has been held that the share of partnership income for a period after a deceased partner's death which was paid to his estate was not taxable to the surviving partners but was taxable as income to the deceased partner's estate. ${ }^{114}$ Similarly, where the partnership agreement provided that on the death of a partner the surviving partner or partners should pay to the deceased partner's widow sums from the partnership income for a specified period and it was found that the income was not used to purchase the deceased partner's interest, such income was held taxable to the widow and not to the surviving partners. ${ }^{115}$

On the other hand, in McClennen v. Commissioner, ${ }^{116}$ where the partnership agreement was construed as providing that the share of the estate of a deceased member of a law firm in partnership earnings for a period of eighteen months after death should be applied to purchase the decedent's interest for the surviving partners, it was held that such income was subject to estate tax in the decedent's estate. The Tax Court in its opinion in the Coates case ${ }^{117}$ pointed out that the McClennen case was distinguishable from the Bull case on the ground that in the McClennen case there was a clear recognition that each partner had a valuable capital interest in the partnership assets, and "the effect and intent of the contract was clearly to make a sale of such an interest to the surviving partners."

In cases where it appeared from the partnership agreement that a share of partnership income for a period after a partner's death was to be applied toward the purchase of the decedent's interest for the surviving partners, such income was held taxable to the survivors and not to the deceased partner's estate. ${ }^{118}$

\section{Basis of Assets to Partnership}

Where remaining partners purchased the interest of a retiring partner and by agreement continued the business without interruption under the same firm name, it was held that the basis for computing gain or loss on the sale of assets by the partnership remained unchanged.118 Similarly, where provision is made for continuation of

114. John G. Madden, 5 CCH TC MEM. DEc. 559 (1946) ; Richard P. Hallowell, 39 B.T.A. 50 (1939); Walter T. Gudeon, 32 B.T.A. 100 (1937).

115. Sidney Hess, 12 T.C. 773 (1949); Gussie K. Barth, 35 B.T.A. 546 (1937).

116. 131 F.2d 165 (1st Cir. 1942).

117. See text at note 112 supra.

118. Wilkins v. Comm'r, 161 F.2d 830 (1st Cir. 1947); W. Frank Carter, 36 B.T.A. 60 (1937) ; Estate of Bavier C. Miller, 38 B.T.A. 487 (1938) ; Hill v. Comm'r, 38 F.2d 165 (1st Cir.), cert. denied, 281 U.S. 761 (1930) ; Pope v. Comm'r, 39 F.2d 420 (1st Cir. 1930).

119. Robert E. Ford, 6 T.C. 499 (1946). 
the partnership without interruption by a partner's death or withdrawal, it has been held that the holding period of a partner's interest for computing capital gain on its sale runs from the time of original acquisition and is not affected by intervening deaths of partners. ${ }^{120}$

First National Bank of Mobile v. Commissioner ${ }^{121}$ involved income tax of the estate of a deceased member of a partnership which continued after his death, where the estate participated in its earnings. Although the decedent's interest in the partnership inventory was included in the estate tax return at a value higher than its cost to the firm, it was held that in computing the estate's share of partnership income for the taxable year, the cost of the inventory to the firm must be used and that the estate was not entitled to reduce its share of income by the difference between its share of such cost and the value at which its share of the inventory was included in the estate tax return. It should follow that where the value of the inventory or other partnership assets has declined, the estate is entitled to compute its income by using the cost of such assets to the firm. This might result in an allowable income tax loss to the estate in excess of the value of the partnership interest for estate tax purposes.

\section{OTHER INCOME}

\section{Gains on Sales Contracted for by Decedent}

In a case which arose under the pre-1942 statute the decedent, who died March 24, 1938, had made an offer to sell certain patents at a specified price, provided the offer was accepted in writing on or before March 25, 1938. There was no acceptance and no sales agreement until the latter date. The Board of Tax Appeals held that no binding agreement was made before the decedent's death and that the gain on the sale was not includible in the decedent's final return. ${ }^{122}$. The Board referred with approval to the Government's contention that if there had been a binding agreement during the decedent's lifetime, the profit would be taxable in the decedent's final return.

There is nothing in Section 126 which throws any light on the treatment of gain represented by payments made after death on account of a sale for which the decedent contracted during his lifetime. The present Bureau position appears to be that gain based on the cost of the property to the decedent is not taxable to the recipient under Section 126 unless the sale was consummated by the decedent during his lifetime.

120. Comm'r v. Lehman, 165 F.2d 383 (2d Cir. 1948).

121. 183 F.2d 172 (5th Cir. 1950), cert. denied, 340 U.S. 911 (1951).

122. Estate of C. William Meinecke, 47 B.T.A. 634 (1942). 
The report of the Senate Finance Committee on the Revenue Bill of 1942, in giving examples of the application of Section 126(a), makes the following statement:

". . Another example is the case of a partner who contracts in the partnership agreement that his interest in certain partnership assets shall pass to the surviving partners in exchange for payment to be made by them to his widow. On his death, the payments by the surviving partners shall be included in the widow's income to the extent they represent the gain on such sale." 123

The committee report does not say whether the gain to be taxed to the widow is to be computed by using the deceased partner's basis for his interest.

The regulations issued under Section 126 which were in force prior to 1945 contained the following sentences:

“. . Furthermore, if his partnership agreement had provided for the sale to the other partners upon his death of his right to the partnership assets in return for a payment of a certain sum by the surviving partners to his estate, the gain on such sale, accrued solely by reason of his death, would not be included in computing his net income.

". .

“. . Upon his death, the payments by the surviving partners must be included in the widow's income to the extent they exceed the adjusted basis of such assets in the hands of the decedent immediately prior to his death." 124

The above sentences were stricken from the regulations in 1945 by T.D. $5459 .^{125}$ The regulations as so amended and as now in force contain the following example:

"Suppose that A and the decedent B were equal partners in a business possessed of tangible assets having a present value considerably in excess of cost; suppose that certain current partnership business was well advanced toward completion prior to the death of $B$; and suppose that the partnership agreement provided that, upon the death of one of the partners, all partnership assets, including unfinished business, should pass to the surviving partner, and that the surviving partner should make certain payments to the estate of the decedent. To the extent that the payments by $A$ to the estate of B are attributable to B's interest in the previously earned proportion of the unfinished partnership business transactions, their receipt by the estate of $B$

123. Sen. Rep. No. 1631, 77th Cong., 2nd Sess. 101 (1942).

124. U.S. Treas. Reg. 111, §29.126-1 (1943).

125. 1945 Cum. Bulx. 193, amending U.S. Treas. Reg. 111, §29.126-1 (1943). 
will reflect the realization of income. With respect to such portion of the payments by $A$ as is attributable to B's interest in the tangible assets of the partnership which had appreciated in value, no gain to the estate of $B$ will be recognized. If some portion of the payments by $\mathrm{A}$ is attributable to a sale of B's interest in partnership assets consummated by B prior to his death, however, the gain to the estate of B reflected in such payments will be recognized regardless of the character of the assets sold, and regardless of whether or not payment was due on a day which must occur after B's death."

The Deputy Commissioner of Internal Revenue in a letter dated August 23, $1945^{\mathbf{1 2 6}}$ refers to the change in the regulations effected by T.D. 5459. The letter rules that where a deceased stockholder during his lifetime entered into a contract with the corporation or with other stockholders in which the corporation or other stockholders agreed to purchase and the decedent agreed that his executors would sell his stock at book value within a specified period after his death, the estate acquired a new basis for the stock on the decedent's death. The ruling states that a new basis is acquired "in those cases in which the sale is not actually consummated prior to death," that is, where the sale is "to be effected only in the event of death."

It appears from the regulations and ruling that the position of the Bureau now is that if the decedent during his lifetime makes an executory contract to sell his partnership interest or other property on his death or on some other contingency which takes place after the date of death, the gain is not taxable as income in respect of a decedent and the estate or legatee acquires a new basis for the property on the decedent's death. On the other hand, where the sale is completely consummated by the decedent during his lifetime, the portion of the proceeds collected by the estate or legatee representing gain to the decedent, if not taxable to the decedent during his lifetime, would be held to constitute income or gain to the recipient, with an allowable deduction for the estate tax paid on such gain. It is not clear what the Bureau's position would be in a case where the decedent during his lifetime entered into a binding contract to sell on a certain date or on the approval of title or the preparation of the papers and where the date falls or the acts are performed after the date of death. ${ }^{127}$ Presumably, if the contract is one which could be enforced by either party during the decedent's lifetime, the Bureau would compute the gain on the basis of the decedent's cost.

126. P-H 1945 FEd. TAX SERv. $\Uparrow 76,295$ (1945).

127. See Lucas v. North Texas Lumber Co., 281 U.S. 11 (1930). 
In Rose J. Linde ${ }^{128}$ the decedent, who owned vineyards, had delivered grapes to cooperative associations for conversion into wine which was to be sold by the associations. The conversion of the grapes into wine and the disposition of the wine did not take place until after the decedent's death. The Commissioner contended that the delivery of the grapes to the cooperatives constituted a sale by the decedent during his lifetime and that proceeds of the liquidation of the wine pools received after his death were taxable under Section 126. The Tax Court held that no sale took place during the decedent's lifetime, that his estate acquired a new basis under Section 113(a)(5) for its interest in the wine pools and that there was no taxable income.

Effect of 1951 Amendment Relating to Long-Term Capital Gain:-Prior to the 1951 amendment discussed below, only 50 per cent of the gain or loss on the sale of a capital asset held for more than six months was taken into account in computing a taxpayer's net capital gain or loss and net income, while 100 per cent of the gain or loss on the sale of a capital asset held for six months or less was so taken into account. ${ }^{129}$ The result was that $\$ 1$ of short-term capital loss could be applied to offset $\$ 2$ of long-term capital gain. Also, under the pre-1951 law, where amounts representing net long-term capital gain were paid to or permanently set aside for charitable organizations, although only 50 per cent was taken into account in computing net income, taxpayers claimed the right to deduct 100 per cent of the amounts under Section 162(a). That claim was ultimately decided adversely to taxpayers. ${ }^{130}$

The statute was amended by the Revenue Act of 1951 so as to include long-term capital gains and losses in gross income at 100 per cent, to allow as a deduction 50 per cent of the excess of net long-term capital gain over net short-term capital loss (resulting in allowing a net long-term capital loss as a deduction in full, subject to the limit of $\$ 1,000$ as the maximum deduction allowable from ordinary income), and to provide that where a deduction is allowable under Section 162(a) for long-term capital gain, proper adjustment of the deduction otherwise allowable shall be made on account of the 50 per cent deduction allowable for the excess of net long-term capital gain over net short-term capital loss. ${ }^{131}$

128. 17 T.C. 584 (1951).

129. INT. Rev. CoDE $\$ 117(b)$.

130. United States v. Benedict, 338 U.S. 692 (1950).

131. Revenue Act of 1951, §322, 65 Stat. 499 (1951), amending INT. REv. CoDE $\$ \$ 117(b)$ and (c) and $162(a)$ (effective for taxable years beginning on or after October 20, 1951). 
Even though Section 126(b) allows as a deduction to the estate or legatee only the deductions in respect of a decedent covered by Section 23(a), (b) and (c), since the section dealing with the determination of capital gain and loss allows a deduction for 50 per cent of the excess of net long-term capital gain over net short-term capital loss, it seems clear that a taxpayer who is required to include in gross income such excess net long-term capital gain in respect of a decedent is entitled to the same 50 per cent deduction to which the decedent would have been entitled. It is not clear whether such taxpayer would be required to reduce the excess net long-term capital gain in respect of a decedent by his own net short-term capital loss in order to arrive at the amount to which the 50 per cent deduction is applicable.

The allowance of 50 per cent of a net long-term capital gain as an income tax deduction, instead of eliminating from income 50 per cent of such gain, would make no difference in the amount of the estate tax attributable to the gain, since the full amount of the gain would be subject to estate tax. However, since the allocation of the estate tax to the taxable years of the estate or legatee is based on gross income in respect of a decedent, and not net income, the changed treatment would make a difference in the proration of the deduction for estate tax to the years in which items of income in respect of a decedent are received by the estate or legatee.

\section{Gain on Installment Obligations}

Where a decedent during his lifetime has elected to report gain on the sale of property on the installment basis under Section 44 of the Code, the decedent's death effects a transmission or realization of all unpaid installment obligations, resulting in the inclusion in the decedent's final return of all gain represented by such obligations. ${ }^{132}$ The taxable gain in such cases is the fair market value of the obligations less the unrecovered basis. However, such gain may be excluded from the decedent's final return if there is filed with the Commissioner at the time prescribed in the regulations a bond conditioned upon the return as income, by the person receiving any payment of such obligations, of the gain on each payment which would be reportable by the decedent if he had lived and received such payment. ${ }^{133}$ The regulations require that the bond be filed by the fiduciary, next of kin or legatee at the time of filing the return for the decedent for the year of his death or at such later time as may be specified by the Commis-

132. Int. Rev. Code $\S 44(d)$.

133. Ibid. 
sioner. ${ }^{134}$ Thus, the executor or other person entitled to receive payment of installment obligations has the option of doing nothing, in which event the gain represented by the unpaid installment obligations will be includible in full in the decedent's final return, or of giving a bond in proper form, so that the gain will be taxable to the estate or other person.

The gain on such unpaid installment obligations is governed by the provisions of the statute relating to installment obligations, and not by Section $126(\mathrm{a})$, so that the gain will be taxable on the decedent's final return unless the required bond is given. However, if the bond is given, the person receiving payment of the installment obligations may be entitled under Section 126 (c) to a deduction for the amount of estate tax attributable to the gain represented in such obligations. Section 126(a) allows such deduction to a person "who includes an amount in gross income" under Section 126(a), and it could be said that the giving of the required bond results in the classification of such gain as gross income in respect of a decedent under Section 126(a). This point is not covered by the regulations or rulings and has not been passed upon by the courts.

Goldberg's Estate v. Commissioner ${ }^{135}$ involved the final income tax return of a decedent who was a member of a partnership which had unreported profits on unpaid installment obligations. The executor contended that the installment obligations could not have been transmitted by the decedent's death, because they were owned by the partnership and not by the decedent. It was held that the decedent's death resulted in a transmission of his share of such obligations and that since no bond was given, his share of the gain was includible in his final return. The court cited Waddell $v$. Commissioner, ${ }^{136}$ in which there was a similar holding.

\section{Long-Term Compensation}

If at least 80 per cent of the total compensation for personal services covering a period of thirty-six or more calendar months is received or accrued in one taxable year by an individual or partnership, then, under the provisions of Section 107 (a) of the Code, the tax attributable to any part of such compensation which is included in the gross income of an individual shall not be greater than the aggregate of the taxes attributable to such part if it had been included in the individual's gross income ratably over that part of the period which preceded the

134. U.S. Treas. Reg. 118, §39.44-5 (1953).

135. 189 F.2d 634 (2d Cir. 1951).

136. 102 F.2d 503 (5th Cir. 1939). 
date of receipt or accrual. The regulations state that it is not necessary, in order for those provisions to apply, that the individual who includes the compensation in gross income be the person who rendered the services, and as an example they say that a partner who shares in the compensation for such services rendered by a partnership is entitled to the benefits of Section 107 (a).$^{137}$

Because of the provisions of Section 126(a)(3) that the right to receive an amount of income in respect of a decedent shall have the same character in the hands of the estate or legatee that it would have had in the hands of the decedent, it seems clear that where the decedent during his lifetime received 20 per cent or less of such longterm compensation and the balance is received by his estate or legatee in one taxable year, the estate or legatee is entitled to the benefits of Section 107 (a). A question which the statute and regulations leave unanswered is whether the tax payable by the estate or legatee on receiving the compensation is limited by the tax which the decedent would have paid on the compensation if he had received it ratably over the period during which the services were rendered or whether the tax is limited by that which would have been so payable on the compensation by the estate or legatee.

Section 126 (a) (3) provides that the right to receive an item of income in respect of a decedent shall be treated in the hands of the estate or legatee as if it had been acquired in the transaction in which the decedent acquired such right, and that provision lends weight to the argument that the tax may be computed by reference to the prior income of the estate or legatee, and not that of the decedent. The fact that the estate was not in existence in the prior periods or that no returns were filed by the estate or legatee for the prior periods would not impair that argument.

The congressional committee reports on the Revenue Bill of 1942 make the following statement:

“. . . If the amounts are compensation for personal services rendered over a period of 36 months, and would be within the provisions of section 107 if the decedent lived and included such amounts in his gross income, section 107 applies. That is, the tax of the person including this amount in gross income attributable to the inclusion of such amount in his income shall not exceed the aggregate of the taxes of the decedent which would be attributable to such amount if it had been received by the decedent in equal portions in each of the months included in the period in which the personal services were rendered." 138

137. U.S. Treas. Reg. $118, \S 39.107-1$ (1953).

138. H.R. ReP. No. 2333, 77th Cong., 2d Sess. $85-86$ (1942) ; SeN. ReP. No. 1631, 77th Cong., $2 \mathrm{~d}$ Sess. 102 (1942). 
That statement indicates an intention of Congress that the tax be computed by reference to the decedent's income for the years in which the services were rendered.

Prior to their amendment in 1944, the regulations contained language substantially identical with the language used in the committee reports. ${ }^{139}$ The regulations were amended in 1944 by striking out that language and inserting in its place a sentence which states: “. . . If the amounts received would be subject to special treatment under Section 107 if the decedent had lived and included such amounts in his gross income, Section 107 applies." 140

There is no record of the reason for the amendment. It is arguable from the amendment that the tax payable on such compensation when received by the estate or legatee may be computed on the basis of the income of the estate or legatee for the period in which the services were rendered.

\section{Interest}

Interest accrued but unpaid at the time of death is includible in the income of the estate or legatee under Section 126(a) in the year of receipt. The regulations provide that the statutory provisions apply to the entire increment accruing on certain United States Treasury bonds and not includible in the decedent's income, where the bonds were owned by the decedent and registered in the names of himself and another as co-owner or beneficiary. ${ }^{141}$

The Tax Court has held that interest on United States Treasury $\mathrm{G}$ Bonds accrued to a decedent at the time of his death is not includible in his gross estate because, although the bonds are redeemable on death at face value, no interest is payable unless the bonds are held on the interest payment date. ${ }^{142}$

\section{Dividends}

In a case which arose under the pre-1942 law, the Supreme Court held that dividends declared prior to death payable to stockholders of record on a date after death were not includible in the final income tax return of a deceased stockholder as income accrued at death. ${ }^{143}$ It would follow under the present law that where a decedent's estate

139. U.S. Treas. Reg. 111, §29.126-1 (1943) (last paragraph).

140. U.S. Treas. Reg. 111, $\$ 29.126-1$ (1943) (last paragraph), as amended, T.D. 5389, 1944 CuM. BuLc. 196.

141. U.S. Treas. Reg. $118, \S 39.126$ (a) -1 (1953).

142. Estate of Willis L. King, Jr., 18 T.C. 414 (1952).

143. Estate of Putnam v. Comm'r, 324 U.S. 393 (1945). 
receives a dividend declared prior to death and the record date is after death, although the dividend is taxable as income to the estate, no income tax deduction is allowable for estate tax paid on the right to receive the dividend. The dividend is reflected in the value of the stock and is not income in respect of a decedent. But where the record date is prior to death and the dividend is received by the estate or legatee, the dividend is valued separately for estate tax purposes and the estate tax is an allowable income tax deduction to the estate or legatee. ${ }^{144}$

\section{Trust Income}

The Bureau has ruled that where a trust has a fiscal year ending after the date of death of the income beneficiary, the beneficiary's final return must include his distributable share of net income received by the trust up to the date of death, and that any trust income accrued but uncollected by the trustee at the time of death which is paid to the decedent's estate is taxable to the estate under Section 126 in the year of receipt. ${ }^{145}$ The ruling finds support in Guaranty Trust Co. $v$. Commissioner ${ }^{146}$ dealing with the taxation of partnership income on the death of a partner.

\section{Trustee's Commissions}

It has been held that where a decedent during his lifetime has earned commissions as trustee, and the commissions are awarded by the state court and paid to his estate after death, they constitute income to the estate under Section 126 in the year of payment. ${ }^{147}$ This is true even though the decedent had no right to receive the commissions until they were awarded by the state court.

\section{Insurance Agent's Renewal Commissions}

It has been generally assumed that where the estate or legatee of a deceased insurance agent has obtained a right to receive amounts representing commissions on premiums paid on the renewal after death of policies written by the agent during his lifetime, the value of such right is an asset which is subject to estate tax in the decedent's

144. See Mable C. Roe, 15 T.C. 503, 510 (1950), rev'd on other grounds, sub nom. Roe v. Comm'r, 192 F.2 398 (5th Cir. 1951).

145. Letter dated February 6, 1947, reported in 1951-52 Montgomery, Estates, Trusts AND GIFTs 246.

146. See text at note 98 supra.

147. Estate of Fred Basch, 9 T.C. 627 (1947). 
estate. Decisions of the Tax Court in Estate of Thomas F. Remington $^{148}$ and Estate of Boyd C. Taylor ${ }^{149}$ hold that amounts received by the decedent's estate on account of such renewal commissions are subject to income tax under Section 126(a), but they throw doubt on whether any amount is subject to estate tax on account of the right to receive such commissions.

In the Remington case the decedent, a broker engaged in selling insurance other than life insurance, had an arrangement with an insurance' brokerage firm whereby he would receive one-half of the commissions on the renewal of policies of customers obtained by him and that on his death the same share of such renewal commissions would be paid to his estate. After the decedent's death his executors purported to sell the decedent's "insurance brokerage business" to the firm in consideration of the payment of one-half of the net commissions received from his customers for a period of approximately six years after his death. It was contended on behalf of the estate that amounts which it received from the firm under such arrangement were exempt from income tax as property received by bequest or inheritance. The Tax Court held such amounts taxable as income to the estate under Section 126. The court relied chiefly on Bull $v$. United States, ${ }^{150}$ which held that a share of partnership earnings received by a deceased partner's estate for a period after death was subject to income tax and not to estate tax. The Tax Court said that, just as in the Bull case, Remington had no investment in the business, the payments to the estate were payments of income, and the mere transfer from the decedent to his estate was no more sufficient to create a basis for the value of his business than was true in the Bull case. The court said further: ". . . we do not have here any interest in a business possessed of tangible assets which would permit us to regard such an interest as a capital asset." 151

In the Taylor case the decedent at the time of his death was a member of a partnership engaged principally in marine insurance underwriting. The partnership agreement gave the decedent's estate an option to become a partner with the other partners to engage in the same type of business for a period of 2,831 days. The estate exercised the option and a new partnership was formed. During the years 1944 and 1945 the estate received approximately $\$ 40,000$ and $\$ 31,500$ as its share of partnership income and not as payment for any share

148. 9 T.C. 99 (1947).

149. 17 T.C. 627 (1951), aff'd per curiam, 200 F.2d 561 (6th Cir. 1952).

150. See text at note 110 supra.

151. 9 T.C. at 107. 
which the decedent may have had in assets of the partnership. The option to participate in the partnership was included in the estate tax return at a value of $\$ 140,000$ and the estate as petitioner claimed a deduction each year for depreciation arrived at by spreading $\$ 140,000$ over a period of 2,831 days. The Tax Court held the deduction not allowable, saying:

“. . . the ruling of the Supreme Court in Bull v. United States, 295 U. S. 247, stands as a barrier to the allowance. In order to sustain petitioner we. would be obliged to find that this right held by petitioner constituted a capital asset which it received from the decedent. We are unable to make such a finding.

". . . We hold that the right inuring to petitioner to receive decedent's share of the partnership income was not capital. Since this right does not constitute capital, petitioner is not entitled to any depreciation thereon." ${ }^{152}$

It is probable that the decisions in the Remington and Taylor cases will lead to litigation involving the question whether any amount is includible in the gross estate of a deceased insurance agent on account of the right of his estate or a legatee to participate in commissions paid on the renewal of policies after the date of death.

Minimization of Income Tax:-It seems clear that all amounts received by the estate or legatee of a deceased insurance agent on account of renewal commissions or a share of the earnings of a partnership receiving such commissions are taxable as income to the estate or legatee under Section 126(a). If the value of the right to receive such commissions or to participate in the partnership earnings is subject to estate tax, an income tax deduction for the estate tax will be allowable under Section 126 (c). Ordinarily, the greater part of such commissions will be received by the estate or legatee within the first two or three years after the decedent's death, resulting in their falling into high income tax brackets. The tax on such amounts would be minimized if the decedent during his lifetime should make an arrangement with the insurance company or the partnership which would provide for payment of a specified amount on account of such commissions to his estate or legatee over a period of years longer than the period in which such payments would be made in the absence of an agreement. Income tax savings may be effected also by bequeathing to more than one taxpayer the right to receive fractional portions of the renewal commissions. 


\section{Alimony}

Arrearages of alimony which would have been taxable as income to a divorced wife if received during her lifetime, to which she had an enforceable right and which were paid to her estate after death have been held to constitute taxable income to the estate under Section $126 .^{153}$

\section{Accounts Receivable}

Where a decedent at the time of his death owned accounts receivable which would have been taxable in full as income to him if collected during his lifetime, it was held that the proceeds of the sale of such accounts by his estate were taxable as income to the estate under Section 126..$^{154}$ The Government conceded that amounts received by the estate on the sale of inventory property were not income to the estate but were a return of capital.

\section{Crops and Raised Livestock}

In a case where a decedent died owning raised cattle and feed and the expense of raising them had been deducted on his income tax returns, but there had been no sale or contract to sell, it was held under the pre-1942 law that their value was not includible as accrued income in the decedent's final return. ${ }^{155}$ It should follow under the present law that crops and raised livestock which have no cost to the decedent take as their basis to the estate or legatee their value for estate tax purposes, that Section 126 does not apply and that only the excess realized on a sale constitutes taxable income or gain..$^{156}$

\section{Conclusion}

Many important problems involving taxation of income attributable to decedents have been decided in the past eleven years by the lower and appellate courts. A number of other problems, resulting from the vague and uncertain language of the statutes and changes in their interpretation by the Bureau of Internal Revenue, remain un-

153. Estate of Sarah L. Narischkine, 14 T.C. 1128 (1950), aff'd per curiam, 189 F.2d 257 (2d Cir. 1951).

154. Dixon v. United States, 96 F. Supp. 986 (E.D. Ky. 1950), aff'd per curiam, 192 F.2d 82 (6th Cir. 1951).

155. Estate of Tom L. Burnett, 2 T.C. 897 (1943).

156. See INT. REv. CoDE $\$ 117(j)$, as amended by Revenue Act of 1951, §323(a), 65 STAT. 500 (1951), which provides in substance that if an unharvested crop on land used in the taxpayer's trade or business and held for more than six months and the land itself are sold at the same time and to the same person, the gain on the sale of the crop is taxable as capital gain. Since the estate or legatee would acquire a new basis for the crop and land on the decedent's death, the estate or legatee must hold them for more than six months in order to obtain the benefit of that provision. 
solved. In the absence of clarifying amendments, it will be several years before all major problems arising under these statutes have been settled by the higher courts. Some of the more important problems would be eliminated and the statute made to operate more equitably if Section 126 were amended to accomplish the following results:

(1) Define income and deductions "in respect of a decedent."

(2) Provide that no income "in respect of a decedent" shall be taxable to the decedent's estate or legatee unless there is a contractual right to receive such income.

(3) Allow a credit, instead of a deduction, for the estate tax on the income tax return, or, in the alternative, make it clear that the income tax payable by the estate or legatee shall be taken into consideration in arriving at the value of such income for estate tax purposes.

(4) Make it clear that any amount includible in the income of an estate under Section 126 may be taken as a deduction under Section 162 (c) if distributed currently to a beneficiary.

(5) Provide that the death of a legatee does not require the inclusion in the legatee's final return of the uncollected portion of the income and that such portion shall be taxed to the legatee's estate or beneficiaries in the years in which received by them. 